Article

\title{
Analysis of the Association Between Meteorological Variables and Mortality in the Elderly Applied to Different Climatic Characteristics of the State of São Paulo, Brazil
}

\author{
Franciele Silva de Barros 1, *, Fábio Luiz Teixeira Gonçalves ${ }^{1}$, João Paulo Assis Gobo ${ }^{2}$ and Júlio \\ Barboza Chiquetto ${ }^{3}$ \\ 1 Departament of Atmospheric Sciences, Institute of Astronomy, Geophysics and Atmospheric Sciences, \\ University of São Paulo (USP), São Paulo, Brazil; fabio.goncaves@iag.usp.br \\ 2 Department of Geography, Federal University of Rondônia (UNIR), Porto Velho, Brazil; joao.gobo@unir.br \\ 3 Institute of Advanced Studies, University of Sao Paulo (USP), São Paulo, Brazil; julio22@gmail.com * \\ Correspondence: franciele_barros_@hotmail.com
}

Received: date; Accepted: date; Published: date

\begin{abstract}
With the rising trends in elderly populations around the world, there is a growing interest in understanding how climate sensitivity is related to their thermal perception. Therefore, we analyzed the associations between mortality in the elderly due to cardiovascular (CVD) and respiratory diseases (RD) and meteorological variables, for three cities in the State of São Paulo, Brazil: Campos do Jordão, Ribeirão Preto and Santos, from 1996 to 2017. We applied the Autoregressive Model Integrated with Moving Average (ARIMA) and the Principal Component Analysis (PCA) in order to evaluate statistical associations. Results showed CVD as a major cause of mortality, particularly in the cold period, when a high mortality rate is also observed due to RD. The mortality rate was higher in Campos do Jordão and lower in Santos (and intermediate values in Ribeirão Preto). Campos do Jordão results indicate an increased probability of mortality from CVD and RD due to lower temperatures. In Ribeirão Preto, the lower relative humidity may be related to the increase in CVD and RD deaths. This study emphasizes that, even among subtropical climates, there are significant differences. Therefore, this can assist decision makers in the implementation of mitigating and adaptive measures.
\end{abstract}

Keywords: Climate, Elderly, Mortality, Meteorological Variables

\section{Introduction}

Climate sensitivity to human health is a widely discussed topic nowadays, mostly due to climate change. Thermal satisfaction with the environment is related to several factors, such as individual, economic, and environmental characteristics.

Extreme or sudden climatic variations may impact the body thermoregulation system, contributing to illness and death [1-3]. In this context, the vulnerability of the elderly requires more attention, as they have reduced capacity for thermoregulation and decreased thermal perception due to body aging, caused by the degeneration of tissues and organs, on top of possibly pre-existing conditions $[4,5]$. Thus, the processes of maintaining body temperature are less efficient, increasing the susceptibility to CVD and RD [6-8]. 
The extensive literature on the associations between climate and mortality in the elderly are particularly focused on high mortality rates due to CVD and RD in colder climate cities [9-14]. However, thermal stress caused by high temperatures is also associated with elderly mortality [15-18].

The most commonly used variables when evaluating thermal comfort are air temperature, humidity, and wind. In cold and dry environments, dehydration and dryness of mucous membranes are more likely to occur, as well as the contamination by infectious agents through air. This is mainly because in cold conditions, people are more likely to gather in closed environments, contributing to the transmission and development of respiratory problems [19-21]. However, the thermoregulation process caused by cold (vasoconstriction) leads to the narrowing of blood vessels, in which the presence of clots and / or fatty plaques can block blood flow to the heart and cause serious problems [22-24].

On the other hand, hot and humid environments favor the proliferation of bacteria, fungi, and mites [25], in addition to increased thermal stress, due to slower sweat evaporation. This makes it difficult for the dissipation of heat and so, the cooling of the body, which might lead to cardiovascular and respiratory disorders [26, 27].

Another important variable, not as much addressed in most studies on this topic, is wind speed, which is associated with the individual's thermal sensation, promoting relief or thermal overload of the thermoregulation mechanisms [20, 28-30].

Gonçalves et al. [31] investigated CVD deaths in the population over 65 years old in São Paulo (SP), from 1996 to 2000, and indicated that the increased risk of CVD mortality was due to the greater thermal stress caused by cold conditions. A study carried out for the city of São Carlos, in the period from 1997 to 2006, revealed that there was a negative correlation between CVD mortality in the elderly and the minimum humidity, that is, deaths were associated with low humidity [32]. According to Bell et al. [15], a study comparing large Latin American cities (Mexico City, Santiago de Chile and São Paulo) reported that the risks of death in the elderly are associated with high temperatures, but the strongest effect was observed in São Paulo, as it was the hottest city in the study.

In this context, there is a constant and worldwide increase in population age. In Brazil, this phenomenon can be explained by the increase in life expectancy of Brazilians due to improved health conditions and the decrease in birth rates [33]. Given the importance of this topic and the lack of studies for some cities in the State of São Paulo, which although it is classified with a subtropical climate, and the cities of study are relatively close to each other, their characteristics are quite different due to slightly different environmental factors.

Therefore, this research aims to analyze their differences and their impacts. Additionally, this study also aims to verify the impacts of meteorological variables on mortality in elderly people due to CVD and RD, in order to guide decision makers to adopt preventive measures focusing on adaptation to extreme cold and heat events, promoting better quality of life for the elderly, particularly in the context of more extreme conditions brought about by climate change in the future.

\section{Materials and Methods}

The effects of climate on health were investigated for three cities in the State of São Paulo: Campos do Jordão $\left(22^{\circ} 45^{\prime} \mathrm{S} 45^{\circ} 36^{\prime} \mathrm{W}\right.$, altitude $\left.1642 \mathrm{~m}\right)$, Ribeirão Preto $\left(21^{\circ} 11^{\prime} \mathrm{S} 47^{\circ} 50^{\prime} \mathrm{W}\right.$, altitude $518 \mathrm{~m}$ ) and Santos $\left(23^{\circ} 55^{\prime} \mathrm{S} 46^{\circ} 17^{\prime} \mathrm{W}\right.$, altitude $9 \mathrm{~m}$ ) (Figure 1 ). 


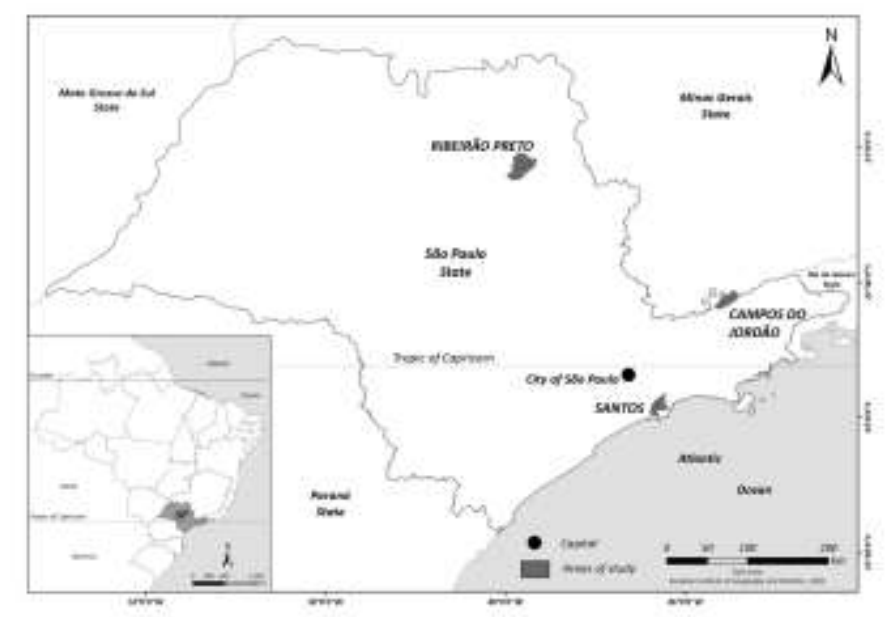

Figure 1 - Map of Brazil with the location of the State of São Paulo and the cities studied.

The period studied was from 1996 to 2017, except in Ribeirão Preto, in which the data correspond to the period from 2000 to 2017 . Only the elderly population was considered (60 years or more). Information on the populations of the cities and the average number of elderly people is shown in Table 1.

\subsection{Mortality Data}

Daily mortality data was obtained for deaths from diseases of the circulatory and respiratory system, according to the International Classification of Diseases (ICD-10) corresponding to I00-I99 and J00-J99, respectively. Data was obtained at the Brazilian Department of Informatics of the Unified Health System (DATASUS). Table 1 shows that the largest elderly population was present in Santos, with an average number of 73551 elderly (17\% of the total population), followed by Ribeirão Preto with 66611 (9.6\%) and Campos do Jordão with 3775 (7.3\%). Due to the differences in the average number of elderly people among cities, during the study period, the number of deaths was lower in Campos do Jordão (1609 CVD and 529 RD), but the percentage of deaths by the average number of elderly people indicated a higher proportion in this city, with $42.6 \%$ of deaths (CVD) and $14 \%$ of deaths (RD), followed by Santos (30.3\% CVD and $12.8 \% \mathrm{RD}$ ), and Ribeirão Preto with $29.4 \%$ of deaths (CVD) and $10.7 \%$ of deaths (RD).

Table 1 - Population and elderly mortality data for CVD and RD, in the period from 1996 to 2017.

\begin{tabular}{ccccc}
\hline Cities & Population $\begin{array}{c}\text { Average } \\
\text { number of } \\
\text { elderly (\%) }\end{array}$ & $\begin{array}{c}\text { oof elderly } \\
\text { deaths due to } \\
\text { CVD (\%) }\end{array}$ & $\begin{array}{c}\text { No of elderly } \\
\text { deaths due to } \\
\text { RD (\%) }\end{array}$ \\
\hline Campos do Jordão & 51.763 & $3.775(7.3)$ & $1.609(42.6)$ & $529(14)$ \\
Ribeirão Preto & 694.534 & $66.611(9.6)$ & $19.581(29.4)$ & $7.095(10.7)$ \\
Santos & 432.957 & $73.551(17)$ & $22.284(30.3)$ & $9.410(12.8)$ \\
\hline
\end{tabular}

${ }^{1} 2018$ population estimates data from the Brazilian Institute of Geography and Statistics (IBGE)[34].

\subsection{Meteorological Data}

Meteorological data of air temperature $(\mathrm{T})$, relative humidity $(\mathrm{RH})$, wind speed $(\mathrm{W})$ and precipitation (PREC) were obtained from meteorological stations of the National Institute of 
Meteorology - INMET (Campos do Jordão), Integrated Center for Agrometeorological Information CIIAGRO (Ribeirão Preto) and the Air Space Control Institute - ICEA (Santos).

\subsubsection{Climate Characterization}

The State of São Paulo is characterized by a subtropical climate influenced by extratropical and tropical synoptic systems, with hot and humid summers, and cool and dry winters [35]. However, there is a distinction in climatic characteristics according to the Köppen-Geiger classification (1928) apud Rolim et al. [36], due to geographical position, relief, altitude and air masses. In view of this, Figure 2 shows the geographical differences among the study areas, responsible for the distinct behavior of meteorological variables (see Table 2). We observed that altitude is one of the main factors that characterize the climate of these areas, since Campos do Jordão is at a higher altitude with a colder climate, Ribeirão Preto is located in the interior of the state with intermediate altitude and dry climate, while Santos it is a coastal city with low altitude and humid and hot climate.

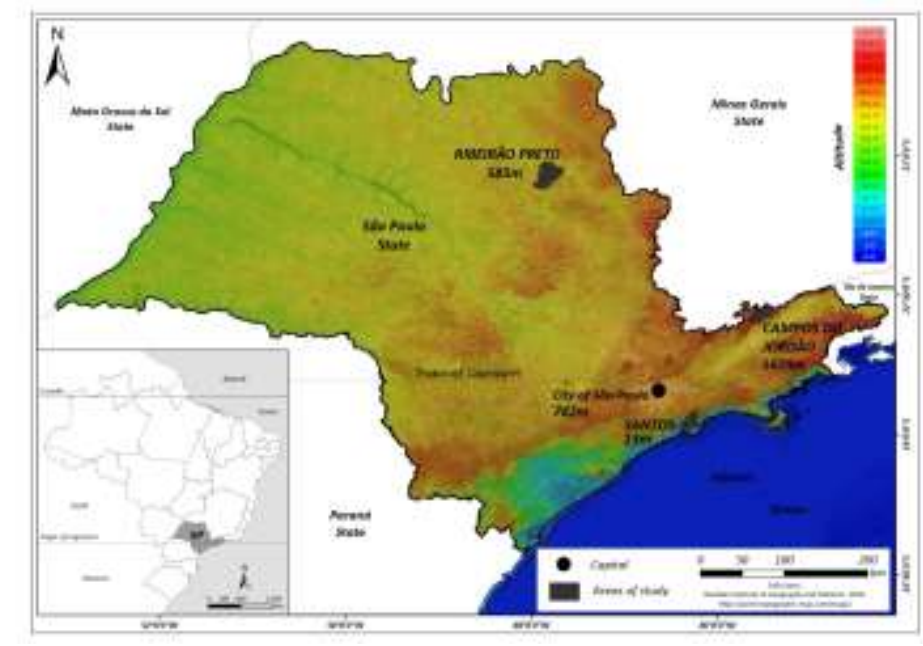

Figure 2 - Topography of the State of São Paulo.

Alvares et al. [37] and Dubreuil et al. [38] conducted studies for Brazil based on the Köppen-Geiger climatic classification. The variability of climatic characteristics of the cities in the study period is shown in Table 2. The climate of Campos do Jordão is classified as oceanic or maritime temperate $(\mathrm{Cfb})^{1}$, which presents milder temperatures with the minimum $\left(-2.2{ }^{\circ} \mathrm{C}\right)$ and maximum $\left(28.8^{\circ} \mathrm{C}\right)$ absolutes, in addition to observing minimum $\mathrm{RH}$ of $30.7 \%$ and average PREC of $1164.6 \mathrm{~mm} \cdot \mathrm{yr}^{-1}$. Ribeirão Preto climate, on the other hand, is classified as semi-humid tropical $(\mathrm{Aw})^{1}$, characterized by a drier climate with a minimum $\mathrm{RH}$ of $14.5 \%$, temperatures ranging between $1.1{ }^{\circ} \mathrm{C}$ (minimum) and $39.4{ }^{\circ} \mathrm{C}$ (maximum), maximum $\mathrm{W}$ of $19 \mathrm{m.} \mathrm{s}{ }^{-1}$ and average PREC of 1133.5 $\mathrm{mm} . \mathrm{yr}^{-1}$. Finally, the climate in Santos is rainy tropical (Af) ${ }^{1}$, revealing that it is hotter than the other cities in the study with maximum $\left(41^{\circ} \mathrm{C}\right)$ and minimum $\left(5.4^{\circ} \mathrm{C}\right)$ temperatures, on the other hand, the minimum RH is $26.5 \%$ and average PREC $1037.3 \mathrm{~mm} . \mathrm{yr}^{-1}$.

${ }^{1}$ Center of Meteorological and Climate Research Applied to Agriculture. Climate of the cities of São Paulo [39]. 
Table 2 - Descriptive statistics of meteorological variables with mean, absolute minimum, and maximum values and standard deviation for the cities studied.

\begin{tabular}{|c|c|c|c|c|}
\hline Variables & Descriptive statistics & Campos do Jordão & Ribeirão Preto & Santos \\
\hline \multirow{4}{*}{$\mathrm{T}\left({ }^{\circ} \mathrm{C}\right)$} & Mean & 17.2 & 23.2 & 23.7 \\
\hline & Minimum & -2.2 & 1.1 & 5.4 \\
\hline & Maximum & 28.8 & 39.4 & 41.0 \\
\hline & Standard Deviation & 3.4 & 3.1 & 3.5 \\
\hline \multirow{4}{*}{ RH (\%) } & Mean & 79.5 & 66.3 & 77.7 \\
\hline & Minimum & 30.5 & 14.5 & 26.5 \\
\hline & Maximum & 100 & 100 & 100 \\
\hline & Standard Deviation & 11.1 & 13.0 & 9.4 \\
\hline \multirow{4}{*}{$\mathrm{W}\left(\mathrm{m} \cdot \mathrm{s}^{-1}\right)$} & Mean & 1.2 & 3.79 & 2.3 \\
\hline & Minimum & 0 & 0 & 0 \\
\hline & Maximum & 8.6 & 19.0 & 10.5 \\
\hline & Standard Deviation & 1.0 & 3.0 & 1.0 \\
\hline \multirow{4}{*}{$\begin{array}{c}\text { PREC } \\
\left(\mathbf{m m} \cdot \mathbf{y r}^{-1}\right)\end{array}$} & Mean & 1164.61 & 1133.5 & 1037.3 \\
\hline & Minimum & 735.4 & 716.7 & 624.0 \\
\hline & Maximum & 1941.0 & 1566.6 & 1518.8 \\
\hline & Standard Deviation & 494.4 & 255.6 & 322.8 \\
\hline
\end{tabular}

\subsection{Calculation of the Mortality Rate (MR)}

To compare the intensity of mortality among cities, we calculated the crude mortality rate - A.10 suggested by the Indicators and Basic Data [40], as there are differences between the number of inhabitants in the cities studied (Table 1). The calculation was performed separately for circulatory and respiratory system mortality, considering only the elderly, obtaining annual and monthly rates. The calculation is given by equation (1):

$$
\mathrm{MR}=\frac{\text { Total number of deaths in elderly residents }}{\text { resident elderly population }} * 1000
$$

\subsection{Statistical methods}

The statistical analyses applied in this work aim to adjust the data to obtain a better understanding of the observations and to investigate the impact of climate on elderly mortality. In this stage, evaluations were carried out for the entire period and separately for the cold (April, May, June, July, August, September) and warm periods (October, November, December, January, February, March).

In order to smooth the time series data, the 1970 Box and Jenkins methodology was applied, which aims to adjust the ARIMA model to a set of data to provide a better understanding [41]. Based on the Autoregressive Moving Average model (ARMA), the ARIMA model incorporates an integrated term (I), in which it differentiates the time series to make it stationary. The non-seasonal ARIMA model is called ( $p, d, q$ ), where $p$ is the order of the autoregressive component, $d$ is the series differentiation number and $\mathrm{q}$ is the order of the moving average component.

The purpose of using Principal Component Analysis was to verify the association between meteorological variables and mortality from CVD and RD in the elderly. This statistical technique is used to reduce the dimension of data with little loss of information, allowing identifying patterns in the data and expressing them through the clustering of objects [42, 43]. The VARIMAX rotation was used to capture the maximum variance, to improve the interpretation, minimizing the number of variables with high loads in each factor $[44,45]$. Analyzes were performed considering lags of 0 to 5 days. Despite the very small variation in the values of the principal components between the days, 
we chose to use lag 3 , because the commonality values (the proportion of the variance of a variable explained by all common factors) were slightly higher.

The statistics covered in this study were performed using RStudio Software, using a significance level of 0.05 for all methods.

\section{Results}

\subsection{Descriptive analyzes}

We analyzed the climatic characteristics of the study period through the behavior of the annual cycle with data obtained from the meteorological stations

Figure 3a shows the monthly average temperature of the cities studied. Campos do Jordão shows average temperatures between $10{ }^{\circ} \mathrm{C}$ and $16{ }^{\circ} \mathrm{C}$, with lower values from May to July. A maximum average temperature of $20^{\circ} \mathrm{C}$ (January) is observed in Ribeirão Preto, and a minimum average of $12{ }^{\circ} \mathrm{C}$ (July) [37]. The greatest variations in average temperature occur in Santos (15 to 25 $\left.{ }^{\circ} \mathrm{C}\right)$, with high temperatures until April [46, 47].

The monthly average of relative humidity in Campos do Jordão indicates a minimum of $70 \%$ (August) and a maximum of $85 \%$ (March). The lowest values of relative humidity are present in Ribeirão Preto, with fluctuations from 60\% (August) to 75\% (January), with June to August the driest months. However, the relative humidity in Santos was mostly constant throughout the cycle, approximately $80 \%$, due to the proximity to the ocean (Figure $3 \mathrm{~b}$ ).

As seen in Figure 3c, Campos do Jordão shows the lowest wind speeds and fluctuations throughout the annual cycle. However, the highest wind speed values were observed in Ribeirão Preto with $3 \mathrm{~m} . \mathrm{s}^{-1}$ (May) and $4.5 \mathrm{~m} . \mathrm{s}^{-1}$ (September). The wind speed was weaker in Santos than in Ribeirão Preto (2 to $2.5 \mathrm{~m} . \mathrm{s}^{-1}$ ).

As mentioned above, the rainfall regime in the State of São Paulo consists of a rainy (summer) and a dry (winter) period [35, 48]. In Figure 3d, the monthly average precipitation in Campos do Jordão is highest in December (200 mm). From April to August, there is minimal precipitation $(50 \mathrm{~mm})$. The highest rainfall in Ribeirão Preto is in January $(250 \mathrm{~mm})$ and the lowest values are present from June to August [37, 49]. Santos shows the best rainfall distribution throughout the annual cycle, with a maximum in January $(150 \mathrm{~mm})$ and a minimum in August (50 $\mathrm{mm})[46,47]$.
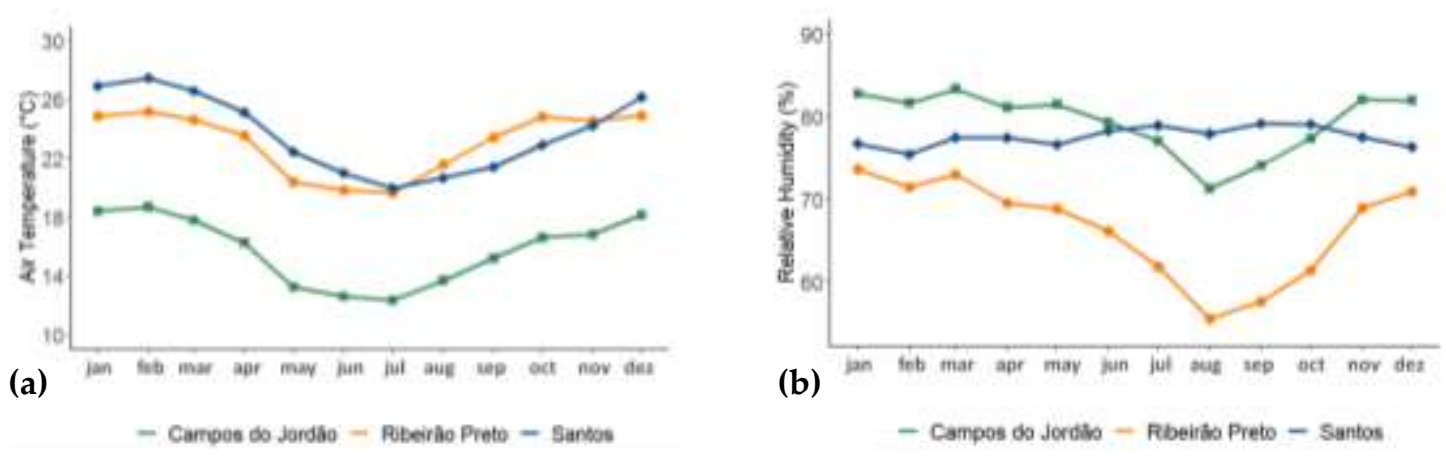

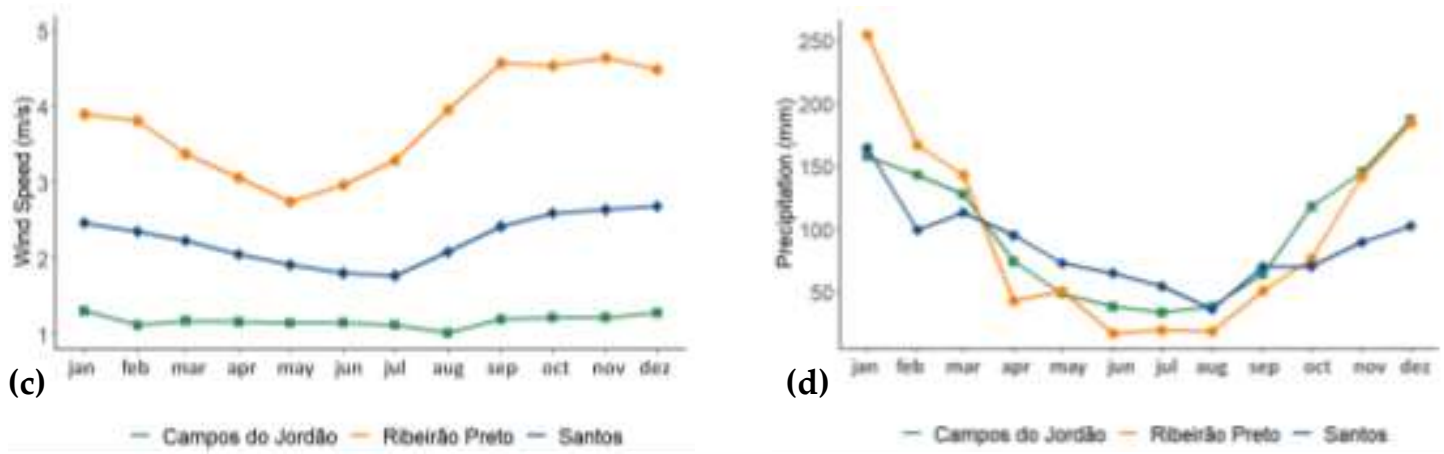

Figure 3 - Annual cycle with the monthly averages of (a) average temperature, (b) relative humidity, (c) wind speed, and (d) precipitation, for the cities studied.

The calculated values of mortality rates are shown in Figure 4 . The highest annual mortality rate for CVD was Campos do Jordão (from 12 to 32\%), followed by Ribeirão Preto (from 11 to $18 \%$ ) and then Santos (13 to 16\%). Ribeirão Preto and Santos displayed similar patterns, possibly because the number of elderly people in these cities is similar (Table 1). Thus, the annual mortality rates due to RD also show similar values in Campos do Jordão (2 to 10\%) and Ribeirão Preto (2 to 7\%), while Santos presented the lowest rate, around 5\% (Figure 4a).

As per Figure $4 \mathrm{~b}-\mathrm{d}$, the highest mortality rates due to CVD and RD for the cities studied occurred in the cold period. The rate was higher in Campos do Jordão (approximately 3\% CVD and $1.5 \% \mathrm{RD}$ ), while Santos presented the lowest rate (approximately 1\% CVD and 0.5\% RD).The warm period also showed a higher mortality rate for Campos do Jordão (approximately $2 \%$ CVD and $1 \%$ $\mathrm{RD}$ ) and a minimum for RD in Santos.

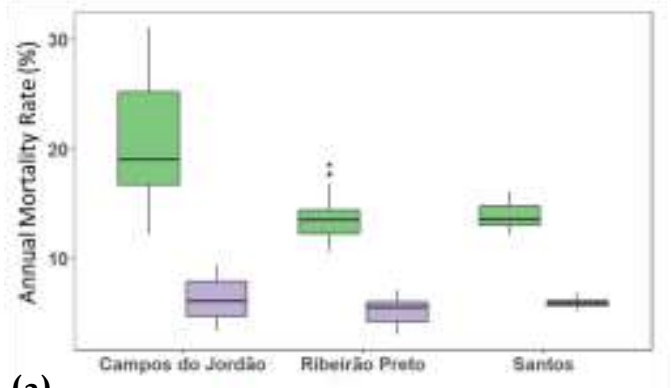

(a)

$\doteq$ Cardiovascular $\notin$ Respiratory

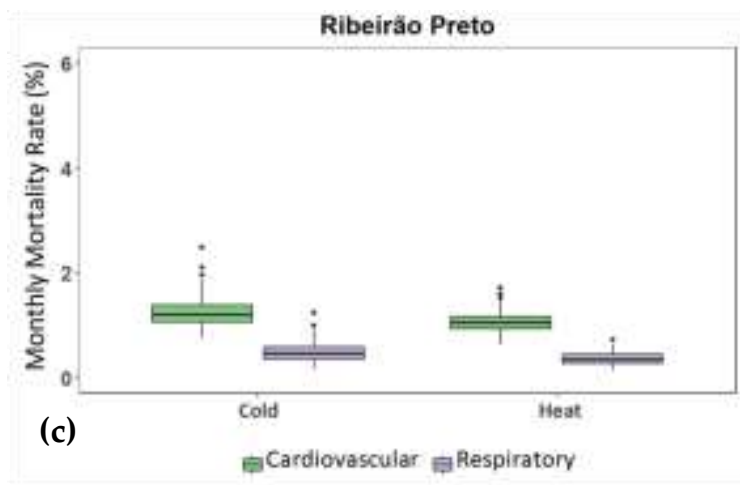

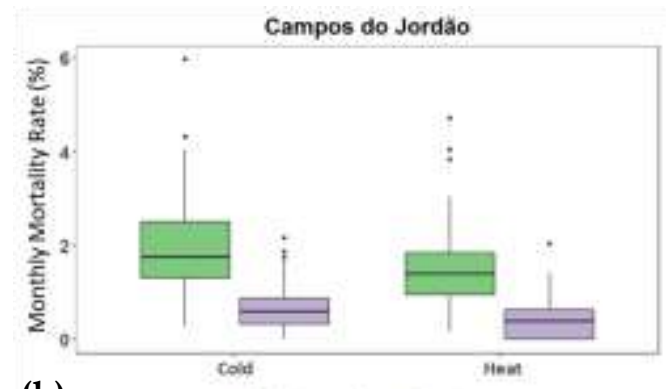

(b)

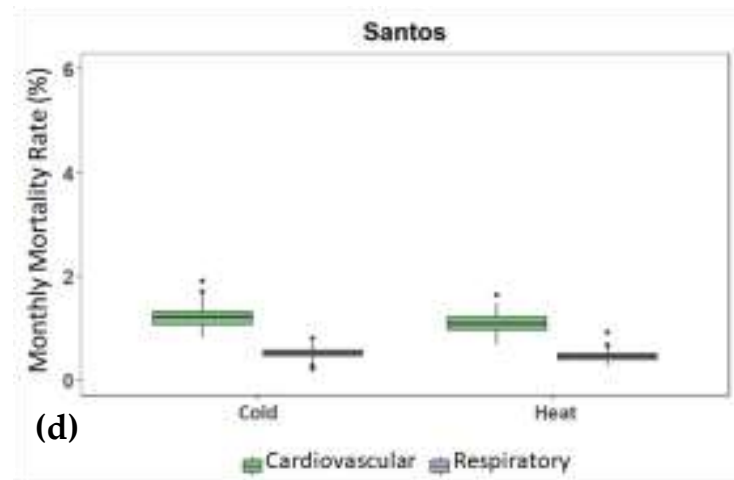

Figure 4 - (a) Annual mortality rates due to CVD and RD, for all cities studied, and monthly mortality rate due to CVD and RD in (b) Campos do Jordão, (c) Ribeirão Preto and (d) Santos, in the cold and warm periods.

\subsection{Statistical analysis}

The Principal Component Analysis results are presented in tables 3 to 8 show commonality $\left(h^{2}\right)$ and the three factors found through the VARIMAX rotation. The method was applied considering 
the meteorological variables (average temperature, relative humidity, and wind speed) and the number of deaths from CVD and RD for the entire study period using lag 3. We divided the analysis between cold and warm periods.

The three factors in Campos do Jordão amounted for $70 \%$ of the explained variance. The first component explained $27 \%$ of the variance of mortality from $\mathrm{RD}$ with a weak negative association (0.31) with temperature $(-0.74)$ and a weak positive association with wind speed (0.83). Factor 2 showed that $22 \%$ of the total variance was explained by the strong association with mortality from CVD (0.90), and by the weak association with deaths from RD (0.46) under the negative influence of temperature $(-0.23)$. In factor 3 , we found that mortality from $\mathrm{RD}(0.25)$ was negatively associated with temperature $(-0.22)$ and wind speed $(-0.23)$, and positively associated with relative humidity (0.93), explaining $21 \%$ of the variance.

Table 3 - PCA of mortality and meteorological variables for Campos do Jordão for the entire period with lag 3.

\begin{tabular}{cccccccc}
\hline Campos do Jordão & CVD & RD & T & RH & W & Eigenvalue & Var Expl. (\%) \\
\hline Factor 1 & -0.06 & $0.31^{*}$ & $\mathbf{- 0 . 7 4}$ & -0.03 & $\mathbf{0 . 8 3}$ & 1.33 & 27 \\
Factor 2 & $\mathbf{0 . 9 0}$ & $0.46^{*}$ & $-0.23^{*}$ & -0.04 & 0.11 & 1.08 & 22 \\
Factor 3 & -0.15 & $0.25^{*}$ & $-0.22^{*}$ & $\mathbf{0 . 9 3}$ & $-0.23^{*}$ & 1.06 & 21 \\
$\mathbf{h}^{\mathbf{2}}$ & 0.83 & 0.36 & 0.65 & 0.87 & 0.75 & Total & 70 \\
\hline
\end{tabular}

Statistically significant correlations in bold and weak associations with $\left({ }^{*}\right)$.

The variance in the cold period was explained by $72 \%$ by the three factors. A percentage of $23 \%$ of the variance was explained by the second factor, from the weak negative association between CVD mortality (-0.25) with temperature (-0.36) and wind speed $(-0.23)$, and positive association with relative humidity (0.89), besides the strong positive relationship with deaths from RD.

The explained variance of the warm period was $73 \%$. The first factor explained $28 \%$ of the variance, with a weak negative association between mortality from RD $(0.31)$ with temperature $(-0.70)$, but positively with wind speed $(0.88)$.

Table 4 - PCA of mortality and meteorological variables for Campos do Jordão for the cold and warm periods.

\begin{tabular}{ccccccccc}
\hline Period & Campos do Jordão & CVD & RD & T & RH & W & Eigenvalue & Var Expl. (\%) \\
\hline \multirow{4}{*}{ Cold } & Factor 1 & 0.04 & 0.06 & $\mathbf{- 0 . 7 7}$ & 0.01 & $\mathbf{0 . 8 7}$ & 1.35 & 27 \\
& Factor 2 & $-0.25^{*}$ & $0.31^{*}$ & $-0.36^{*}$ & $\mathbf{0 . 8 9}$ & $-0.23^{*}$ & 1.14 & 23 \\
& Factor 3 & $\mathbf{0 . 7 9}$ & $0.66^{*}$ & -0.13 & -0.01 & 0.01 & 1.08 & 22 \\
& $\mathbf{h}^{\mathbf{2}}$ & 0.7 & 0.53 & 0.74 & 0.8 & 0.81 & Total & 72 \\
\hline \multirow{4}{*}{ Warm } & Factor 1 & -0.16 & $0.31^{*}$ & $\mathbf{- 0 . 7}$ & -0.05 & $\mathbf{0 . 8 8}$ & 1.4 & 28 \\
& Factor 2 & 0.1 & -0.09 & $-0.54^{*}$ & $\mathbf{0 . 9 4}$ & -0.13 & 1.21 & 24 \\
& Factor 3 & $\mathbf{0 . 8 6}$ & $0.54^{*}$ & 0.04 & 0.03 & 0.08 & 1.04 & 21 \\
& $\mathbf{h}^{\mathbf{2}}$ & $\mathbf{0 . 7 7}$ & 0.4 & $\mathbf{0 . 7 9}$ & $\mathbf{0 . 8 8}$ & $\mathbf{0 . 8}$ & Total & 73 \\
\hline
\end{tabular}

Statistically significant correlations in bold and weak associations with $\left(^{*}\right)$.

For Ribeirão Preto, the three factors explained $79 \%$ of the variance, with $31 \%$ from the first factor, in which CVD mortality (0.83) showed a strong negative association with relative humidity $(-0.87)$. Nevertheless, we also found that mortality from RD $(0.34)$ had a weak negative association with relative humidity. The explained variance of factor $2(26 \%)$ indicated a strong negative association of mortality from RD (-0.64) with temperature (0.92). The third factor explained $22 \%$ of the variance, confirming the existence of a weak negative association of mortality from RD (-0.29) with wind speed (0.96).

Table 5 - PCA of mortality and meteorological variables for Ribeirão Preto for the entire period with lag 3. 


\begin{tabular}{cccccccc}
\hline Ribeirão Preto & CVD & RD & T & RH & W & Eigenvalue & Var Expl. (\%) \\
\hline Factor 1 & $\mathbf{0 . 8 3}$ & $0.34^{*}$ & 0.09 & $\mathbf{- 0 . 8 7}$ & 0.09 & 1.57 & 31 \\
Factor 2 & -0.18 & $-0.64^{*}$ & $\mathbf{0 . 9 2}$ & -0.07 & 0.06 & 1.28 & 26 \\
Factor 3 & -0.1 & $-0.29^{*}$ & -0.07 & $-0.23^{*}$ & $\mathbf{0 . 9 6}$ & 1.08 & 22 \\
$\mathbf{h}^{\mathbf{2}}$ & 0.73 & 0.6 & 0.85 & 0.81 & 0.94 & Total & 79 \\
\hline
\end{tabular}

Statistically significant correlations in bold and weak associations with $\left.{ }^{*}\right)$.

In the cold period, the three factors explained $81 \%$ of the variance. The first factor explained $33 \%$ of the variance, with a strong negative association between mortality from CVD (0.85) and RD (0.64) with relative humidity (-0.70). The explained variance of factor $2(25 \%)$ showed a weak negative association of mortality from $\mathrm{RD}(-0.40)$ with relative humidity $(-0.48)$ and positive with wind speed (0.94). Factor 3 explained $23 \%$ of the variance through the weak negative association between mortality from RD (-0.26) and relative humidity $(-0.35)$ and positive association with temperature (0.97).

The sum of the explained variance of the three factors found in the warm period represented $75 \%$ of total variance. Factor 1 explained $33 \%$ of the variance through mortality from CVD (0.74) associated negatively, and strongly, with relative humidity (-0.91), and positively, with temperature (0.35) and wind speed (0.38).

Table 6 - PCA of mortality and meteorological variables for Ribeirão Preto for the cold and warm periods.

\begin{tabular}{ccccccccc}
\hline Period & Ribeirão Preto & CVD & RD & T & RH & W & Eigenvalue & Var Expl. (\%) \\
\hline \multirow{4}{*}{ Cold } & Factor 1 & $\mathbf{0 . 8 5}$ & $0.64^{*}$ & -0.05 & $\mathbf{- 0 . 7 0}$ & -0.01 & 1.63 & 33 \\
& Factor 2 & 0.02 & $-0.40^{*}$ & 0.01 & $-0.48^{*}$ & $\mathbf{0 . 9 4}$ & 1.27 & 25 \\
& Factor 3 & -0.04 & $-0.26^{*}$ & $\mathbf{0 . 9 7}$ & $-0.35^{*}$ & -0.02 & 1.14 & 23 \\
& $\mathbf{h}^{2}$ & 0.88 & 0.73 & 0.64 & 0.95 & 0.84 & Total & 81 \\
\hline \multirow{3}{*}{ Warm } & Factor 1 & $\mathbf{0 . 7 4}$ & -0.02 & $0.35^{*}$ & $\mathbf{- 0 . 9 1}$ & $0.38^{*}$ & 1.64 & 33 \\
& Factor 2 & 0.11 & -0.02 & $\mathbf{- 0 . 7 9}$ & 0.15 & $0.68^{*}$ & 1.12 & 22 \\
& Factor 3 $^{*}$ & -0.02 & $\mathbf{0 . 9 9}$ & 0.14 & -0.01 & 0.11 & 1.01 & 20 \\
& $\mathbf{h}^{\mathbf{2}}$ & 0.57 & 0.98 & 0.76 & 0.84 & 0.62 & Total & 75
\end{tabular}

Statistically significant correlations in bold and weak associations with $\left(^{*}\right)$.

According to Santos' analyzes, the three factors explained $77 \%$ of the variance. The second factor explained $22 \%$ of the variance, due to mortality from RD (0.96), which showed a weak negative association with wind speed. (-0.39). Factor 3 showed the weak negative relationship between CVD mortality (0.96) and wind speed (-0.31) and explained $22 \%$ of the variance.

Table 7 - PCA of mortality and meteorological variables for Santos for the entire period with lag 3.

\begin{tabular}{cccccccc}
\hline Santos & CVD & RD & T & RH & W & Eigenvalue & Var Expl. (\%) \\
\hline Factor 1 & -0.05 & -0.01 & $\mathbf{0 . 8 1}$ & $\mathbf{- 0 . 8 2}$ & $0.56^{*}$ & 1.65 & 33 \\
Factor 2 & 0.08 & $\mathbf{0 . 9 6}$ & -0.11 & -0.12 & $-0.39^{*}$ & 1.10 & 22 \\
Factor 3 & $\mathbf{0 . 9 6}$ & 0.07 & -0.19 & -0.17 & $-0.31^{*}$ & 1.09 & 22 \\
$\mathbf{h}^{2}$ & 0.94 & 0.92 & 0.71 & 0.72 & 0.57 & Total & 77 \\
\hline
\end{tabular}

Statistically significant correlations in bold and weak associations with $\left(^{*}\right)$.

A percentage of $73 \%$ of the variance in the cold period for was explained by the three factors in Santos. The second factor explained $23 \%$ of the variance, in which mortality from RD (0.90) showed a negative association with wind speed (-0.54), followed by factor 3 , which accounted for CVD 
mortality (0.97) being associated negatively with temperature (-0.33), which explained $21 \%$ of the variance.

The variance of the warm period was explained by $76 \%$, of which the second factor represented $23 \%$, in which mortality from RD (-0.55) was positively associated with wind speed (0.89). The third factor explained $21 \%$ of the variance, where mortality by CVD (0.94) and RD (0.43) are associated.

Table 8 - PCA of mortality and meteorological variables for Santos for the cold and warm periods.

\begin{tabular}{ccccccccc} 
Period & Santos & CVD & RD & T & RH & W & Eigenvalue & Var Expl. (\%) \\
\hline \multirow{3}{*}{ Cold } & Factor 1 & -0.08 & 0.06 & $\mathbf{0 . 7 2}$ & $\mathbf{- 0 . 8 8}$ & $0.42^{*}$ & 1.47 & 29 \\
& Factor 2 & 0.11 & $\mathbf{0 . 9 0}$ & -0.16 & -0.01 & $-0.54^{*}$ & 1.14 & 23 \\
& Factor 3 & $\mathbf{0 . 9 7}$ & 0.10 & $-0.33^{*}$ & -0.08 & -0.06 & 1.06 & 21 \\
& $\mathbf{h}^{2}$ & 0.95 & 0.83 & 0.65 & 0.78 & 0.47 & Total & 73 \\
\hline \multirow{2}{*}{ Warm } & Factor 1 & -0.03 & 0.15 & $\mathbf{0 . 8 9}$ & $\mathbf{- 0 . 8 7}$ & 0.17 & 1.60 & 32 \\
& Factor 2 & -0.07 & $-0.55^{*}$ & -0.06 & -0.15 & $\mathbf{0 . 8 9}$ & 1.13 & 23 \\
& Factor 3 & $\mathbf{0 . 9 4}$ & $0.43^{*}$ & -0.06 & -0.08 & 0.01 & 1.07 & 21 \\
& $\mathbf{h}^{\mathbf{2}}$ & 0.89 & 0.50 & 0.79 & 0.79 & 0.83 & Total & 76 \\
\hline
\end{tabular}

Statistically significant correlations in bold and weak associations with $(*)$.

\section{Discussion}

The investigations carried out in this study address the importance of understanding how different climatic characteristics present in each city affect the mortality of the elderly. Results showed the predominance of cardiovascular diseases in the mortality rate for all studied cities [32], due to the fact that this type of disease can be influenced by several factors, including behavior (tobacco, alcohol, obesity, sedentary lifestyle and others) [50].

The highest mortality rates due to CVD and RD for the study period were observed in Campos do Jordão, 12 to $32 \%$ and 2 to $5 \%$, respectively. It is considered one of the coldest cities in Brazil [51], and so, thermal stress to cold may have contributed to the occurrence of deaths [13, 52]. The statistical associations found for Campos do Jordão revealed a possible role of low temperature in mortality, but deaths from RD can also be influenced by high relative humidity and wind speeds that impair human thermal comfort $[10,53,54]$.

Ribeirão Preto is the second city with the highest mortality rate. Low relative humidity values are observed throughout the year, characterizing a dry climate. The statistical associations indicated that this climate may influence deaths, as dry air can cause mucous membranes to become excessively dry and more prone to infectious agents and dehydration, causing serious health consequences [6,32]. Also, we observed a decrease in deaths from RD due to higher temperatures and the high wind speeds, which may decrease thermal stress to cold.

On the other hand, Santos showed a mortality rate slightly lower than Ribeirão Preto $(\sim 15 \%$ CVD and $\sim 5 \% \mathrm{RD}, \sim 16 \% \mathrm{CVD}$ and $\sim 6 \% \mathrm{RD}$, respectively). This may be a consequence of the decrease in thermal sensation in coastal cities, where the presence of the ocean softens the climate, favoring thermal comfort $[47,55]$, in addition to being less cold (see Figure 2a). Besides, the lower percentage of deaths from RD may be associated with high relative humidity in the city, being consistent with studies that show the greater impact of low relative humidity on RD [19, 56]. According to the principal component analysis, the lower wind speed values may be associated with CVD and respiratory deaths in Santos. This relationship can be explained by the city's climatic characteristics (hot and humid), where higher wind speed values would help relieving the thermal stress [29].

The analysis of the mortality rates is very important to alert the populations, particularly the most vulnerable groups, about the highest incidence of mortality in the warm and cold periods, 
enabling increased prevention. The cold period showed a higher mortality rate for the cities studied. Thus, the statistical analyzes carried out in the cold period for Campos do Jordão revealed the influence of low temperature, high levels of relative humidity and calm winds in the increase of deaths due to RD. A cold and humid environment can favor the spreading of infectious agents [25], contributing to the development of $\mathrm{RD}$. Also, the warm period demonstrated that the effects of low temperature can be enhanced by strong winds, increasing discomfort to the cold. However, deaths due to CVD did not obtain statistical significance in any of the periods in this city.

In the cold period, the relative humidity reaches minimum values that can contribute to the increase in mortality in Ribeirão Preto. We emphasize that this season is also favorable for the increase in the concentration of air pollutants, due to the decreased deposition and dispersion of suspended particles, increasing the intake of particulate matter [57], which could exert a greater impact on the number of deaths. However, the warm period is associated to increased mortality from CVD through low humidity, high values of wind speed and high temperature [58].

As analyzed, the increase in mortality due to RD in Santos in the cold period may be related to weaker wind speeds maybe due to the increase of the air pollution, which it is outside of this study focus. However, lower temperatures may be related to the increase in deaths from CVD $[9,14,20$, 59]. Furthermore, mortality from RD may decrease as a consequence of strong winds in the warm period, because it leads to better thermal comfort.

Authors should discuss the results and how they can be interpreted in perspective of previous studies and of the working hypotheses. The findings and their implications should be discussed in the broadest context possible. Future research directions may also be highlighted.

\section{Conclusions}

In this study, we compared CVD and RD mortality rates in cities with different subtropical climatic characteristics in the State of São Paulo (Brazil), in addition to the joint use of the ARIMA and PCA models, which provided satisfactory results.

We identified different behaviors of meteorological variables and mortality for each city. Santos is the city with the highest number and percentage of elderly people and presented the lowest mortality rate, possibly due to the softened climate due to the proximity to the ocean. However, because it is the hottest city in the study, the effect of lower wind speed can predominate in the increase in deaths. However, the intermediate rates of elderly and mortality for Ribeirão Preto indicate that the population is not exposed to such low temperatures and the effects of the dry climate can result in deaths. Meanwhile, Campos do Jordão has the smallest elderly population, and the highest mortality rate, so this can be related to the population's economic vulnerability, and, particularly, to the cold climate due to the higher altitude.

The overall result emphasizes that even slight climatic differences among subtropical cities may cause CVD and RD mortality impacts' changes.

This work shows the relevance in evaluating the climatic impact on the mortality of elderly considering regions with different subtropical climates, aiming to inform society and guide decision makers in the implementation of mitigating and adaptive measures, aiming to provide a better quality of life for the elderly population.

Funding: This research was funded by Coordenação de Aperfeiçoamento de Pessoal de Nível Superior - Brazil (CAPES).

Acknowledgments: The authors thank the Coordination for the Improvement of Higher Education Personnel (CAPES) for financial support, Integrated Center for Agrometeorological Information (CIIAGRO) and Air Space Control Institute (ICEA) for providing the meteorological data.

Conflicts of Interest: The authors declare no conflict of interest.

\section{References}

1. Conlon, K.C.; Rajkovich, N.B.; White-newsome, J.L.; Larsen, L.; Neill, M.S.O. Preventing cold-related 
morbidity and mortality in a changing climate. Maturitas 2011, 69, 197-202. doi:10.1016/j.maturitas.2011.04.004

2. Díaz, J.; García, R.; López, C.; Linares, C.; Tobías, A.; Prieto, L. Mortality impact of extreme winter temperatures. Int. J. Biometeorol. 2005, 49, 179-183. doi:10.1007/s00484-004-0224-4

3. Sette, D.M.; Ribeiro, H. Interações entre o clima, o tempo e a saúde humana. Rev. Saúde Meio Ambient. e Soc. 2011, 6, 37-51.

4. Gobo, J.P. de A.; Galvani, E.; Wollmann, C.A. Influência da faixa etária e do índice de massa corporal na sensação térmica e no conforto térmico da população em Santa Maria-RS , Brasil. Climatol. Apl. II. 2018, 1, 135-142.

5. Vogelaere, P.; Pereira, C. Termoregulação e Envelhecimento. Rev. Port. Cardiol. 2005, 5, 747-761.

6. Costa, E.R.G. A Desidratação no Idoso. Level of Thesis, Degree-Master, Faculdade de Medicina, Universidade de Coimbra, Coimbra, 2015.

7. Goncalves, F.L.T.; Coelho, M. de S.Z.S. Variação Da Morbidade De Doenças Respiratórias Em Função Da Variação Da Temperatura Entre Os Meses De Abril E Maio Em São Paulo. Ciência e Nat. 2010, 32, 103-118. doi:10.5902/2179460X9500

8. Pinto, R.S. da C. O contributo dos SIG para a compreensão da sobremorbilidade por Enfarte Agudo do Miocárdio, nos idosos durante eventos extremos de calor e de frio. Level of Thesis, Degree-Master, Faculdade de Letras, Universidade do Porto, Porto, 2016.

9. Barreca, A.I. Climate change, humidity, and mortality in the United States. J. Environ. Econ. Manage. 2012, 63, 19-34. doi:10.1016/j.jeem.2011.07.004

10. Eurowinter, G. Cold exposure and winter mortality from ischaemic heart disease, cerebrovascular disease, respiratory disease, and all causes in warm and cold regions of Europe. Lancet 1997, 349, 1341-6.

11. Gouveia, N.; Hajat, S.; Armstrong, B. Socioeconomic differentials in the temperature-mortality relationship in São Paulo, Brazil. Int. J. Epidemiol. 2003, 32, 390-397. doi:10.1093/ije/dyg077

12. Ikefuti, P. V.; Barrozo, L. V.; Braga, A.L.F. Mean air temperature as a risk factor for stroke mortality in São Paulo . Int. J. Biometeorol. 2018, 62, 1535-1542 . doi:10.1007/s00484-018-1554-y

13. Martens, W.J.M. Climate change, thermal stress and mortality changes. Soc. Sci. Med. 1998, 46, 331-344. doi:10.1016/S0277-9536(97)00162-7

14. McGeehin, M.A.; Mirabelli, M. The Potential Impacts of Climate Variability and Change on Temperature-Related Morbidity and Mortality in the United States. Environ. Health Perspect. 2001, 109, 185-189.

15. Bell, M.L.; O’Neill, M.S.; Ranjit, N.; Borja-Aburto, V.H.; Cifuentes, L.A.; Gouveia, N.C. Vulnerability to heat-related mortality in Latin America: A case-crossover study in São Paulo, Brazil, Santiago, Chile and Mexico City, Mexico. Int. J. Epidemiol. 2008, 37, 796-804. doi:10.1093/ije/dyn094

16. Hajat, S.; Armstrong, B.G.; Gouveia, N.; Wilkinson, P. Mortality displacement of heat-related deaths: A comparison of Delhi, São Paulo, and London. Epidemiology 2005, 16, 613-620. doi:10.1097/01.ede.0000164559.41092.2a

17. Kalkstein, L.S. A New Approach to Evaluate the Impact of Climate on Human Mortality. Env. Heal. Perspect. 1991, 96, 145-150.

18. Yu, W.; Mengersen, K.; Wang, X. Daily average temperature and mortality among the elderly: a meta-analysis and systematic review of epidemiological evidence. Int. J. Biometeorol. 2012, 56, 569-581. doi:10.1007/s00484-011-0497-3

19. Arundel, A. V.; Sterling, E.M.; Biggin, J.H.; Sterling, T.D. Indirect health effects of relative humidity in indoor environments. Env. Heal. Perspect. 1986, 65, 351-361. doi:10.1289/ehp.8665351

20. Laschewski, G.; Jendritzky, G. Effects of the thermal environment on human health: An investigation of 30 years of daily mortality data from SW Germany. Clim. Res. 2002, 21, 91-103. doi:10.3354/cr021091

21. Shaw Stewart, P.D. Seasonality and selective trends in viral acute respiratory tract infections. Med. Hypotheses 2016, 86, 104-119. doi:10.1016/j.mehy.2015.11.005

22. Gorjanc, M.L.; Flanders, W.D.; VanDerslice, J.; Hersh, J.; Malilay, J. Effects of temperature and snowfall on mortality in Pennsylvania. Am. J. Epidemiol. 1999, 149, 1152-60. doi:10.1093/oxfordjournals.aje.a009770

23. Kalkstein, L.S.; Greene, J.S. An evaluation of climate/mortality relationships in large U.S. cities and the possible impacts of a climate change. Environ. Health Perspect. 1997, 105, 84-93. doi:10.1289/ehp.9710584

24. Kurz, A. Physiology of Thermoregulation. Best Pract. Res. Clin. Anaesthesiol. 2008, 22, 627-644. doi:10.1016/j.bpa.2008.06.004

25. Baughman, A. V.; Arens, E.A. Indoor humidity and human health - Part I: Literature review of health effects of humidity-influenced indoor pollutants. ASHRAE Trans. 1996, 102, 193-211.

26. McMichael, A.J.; Woodruff, R.E.; Hales, S. Climate change and human health: Present and future risks. Lancet 2006, 367, 859-869. doi:10.1016/S0140-6736(06)68079-3 
27. Souza, D.; Santos, S.; Aparecida, D. Hospitalizações por infecção respiratória associada a fatores ambientais. Revista Brasileira em Promoção da Saúde 2014, 27, 312-318.

28. Gobo, A.; Faria, M.R.; Galvani, E.; Cristiane, M.; Trindade, D.C.; Celuppi, M.C.; Wollmann, C.A. Empirical Model of Thermal Comfort for Medium-Sized Cities in Subtropical Climate. Atmosphere 2019, 10, 1-18. doi: 10.3390/atmos10100576

29. Santos, J.B. dos; Amorim, R.F.C.; Cavalcante, L.P.A. Análise do conforto térmico humano no município de Arapiraca - Alagoas, utilizando software Matlab. Rev. Bras. Geogr. Física 2014, 7, 939-948.

30. Gobo, J.P. de A.; Alves, R.R.; Silveira, T.S.; Onça, D. de S.; Monteiro, L.M.; Wollmann, C.A., Galvani, E. A influência do vento regional na sensação térmica de pedestres em espaços urbanos abertos: Estudo de caso do vento norte em Santa Maria-RS. Raega - O Espaço Geográfico em Análise 2017, 1, 111-129. doi:10.5380/raega

31. Gonçalves, F.L.T.; Braun, S.; Silva Dias, P.L.; Sharovsky, R. Influences of the weather and air pollutants on cardiovascular disease in the metropolitan area of São Paulo. Environ. Res. 2007, 104, 275-281. doi:10.1016/j.envres.2007.01.004

32. Soares, F.V. Relationship between climate change and determinant factors of mortality among the elderly in the municipality of São Carlos (São Paulo, Brazil) over a period of ten years. Cien. Saude Colet. 2012, 17, 135-146.

33. Miranda, D.; Morais, G.; Mendes, G.; Cruz, A.; Silva, A.; Lucia, A. O envelhecimento populacional brasileiro: desafios e consequências sociais atuais e futuras. Rev. Bras. Geriatr. e Gerontol. 2016, 19, 507-19. doi:10.1590/1809-98232016019.150140

34. Dados de estimativas de população de 2018. Available online: https://cidades.ibge.gov.br/ (accessed on 01 Aug. 2019)

35. Dufek, A.S.; Ambrizzi, T. Precipitation variability in São Paulo State, Brazil. Theor. Appl. Climatol. 2008, 93, 167-178. doi:10.1007/s00704-007-0348-7

36. Rolim, G. de S.; Camargo, M.B.P. de; Lania, D.G.; De Moraes, J.F.L. Classificação climática de Köppen e de Thornthwaite e sua aplicabilidade na determinação de zonas agroclimáticas para o estado de São Paulo. Bragantia 2007, 66, 711-720.

37. Alvares, C.A.; Stape, J.L.; Sentelhas, P.C.; De Moraes Gonçalves, J.L.; Sparovek, G. Köppen's climate classification map for Brazil. Meteorol. Zeitschrift 2013, 22, 711-728. doi:10.1127/0941-2948/2013/0507

38. Dubreuil, V.; Fante, K.P.; Planchon, O.; Neto, J.L.S. Climate change evidence in Brazil from Köppen ' s climate annual types frequency. Int. J. Climatol. 2018, 1-12. doi:10.1002/joc.5893

39. Clima municípios paulista. Available online: https://www.cpa.unicamp.br/outras-informacoes/clima-dos-municipios-paulistas.html (accessed on 10 Aug. 2018)

40. Indicadores e Dados Básicos - Brasil - 2012. Available online: http://tabnet.datasus.gov.br/cgi/idb2012/matriz.htm (accessed on 02 May 2019).

41. Hyndman, R.J.; Ullah, S. Robust Forecasting of Mortality and Fertility Rates A Functional Data Approach. Computational Statistics and Data Analysis 2007, 51, 4942-4956. doi: 10.1016/j.csda.2006.07.028

42. Lyra, W. da S.; Da Silva, E.C.; De Araújo, M.C.U.; Fragoso, W.D. Classificação periódica: Um exemplo didático para ensinar análise de componentes principais. Química Nova 2010, 33, 1594-1597.

43. Wold, S., Esbensen, K., Geladi, P.: Principal Component Analysis. Chemom. Intell. Lab. Syst. 2, 37-52 (1987). doi:10.1016/0169-7439(87)80084-9

44. Wood, J.M.; Tataryn, D.J.; Gorsuch, R.L. Effects of under- and overextraction on principal axis factor analysis with varimax rotation. Psychol. Methods 1996,1, 354-365. doi:10.1037/1082-989X.1.4.354

45. Kaiser H F: The varimax criterion for analytic rotation in factor analysis. Psychometrika. 23, 187-200 (1958)

46. Lyra, A., Tavares, P., Chou, S.C., Sueiro, G., Dereczynski, C., Sondermann, M., Silva, A., Marengo, J., Giarolla, A.: Climate change projections over three metropolitan regions in Southeast Brazil using the non-hydrostatic Eta regional climate model at 5-km resolution. Theor. Appl. Climatol. 2018, 132, 663-682. doi:10.1007/s00704-017-2067-z

47. Moreira, F.A.; Nunes, L.H.; Paterson, S.; Pelling M. Adaptive Capacity Index: Part II. Santos, Brazil. Contested Development Working Paper Series, Dep. Geogr. King's Coll. London, 77, 2017.

48. Liebmann, B.; Jones, C.; de Carvalho, L.M.V. Interannual variability of daily extreme precipitation events in the state of Saõ Paulo, Brazil. J. Clim. 2001, 14, 208-218. doi:10.1175/1520-0442(2001)014<0208:IVODEP>2.0.CO;2

49. Gabriel, A.F.B.; Abe, K.C.; Guimarães, M. de P.; Miraglia, S.G.E.K. Avaliação de impacto à saúde da incidência de dengue associada à pluviosidade no município de Ribeirão Preto, São Paulo. Cad. Saúde Coletiva 2018, 26, 446-452. doi:10.1590/1414-462×201800040119 
50. Cardiovascular diseases

(CVDs).

Available

online: https://www.who.int/news-room/fact-sheets/detail/cardiovascular-diseases-(cvds)\#: :text=CVDs\%20are\% 20the\%20number\%201,to\%20heart\%20attack\%20and\%20stroke (accessed on 21 May 2020).

51. Prince, A.E. O Clima de Campos do Jordão e a Tuberculose no século XIX. Acta Geográfica 2017, 11, 57-74.

52. Braga, A.L.F.; Zanobetti, A.; Schwartz, J. The Effect of Weather on Respiratory and Cardiovascular Deaths in 12 U.S. Cities. Environ. Health Perspect. 2002, 110, 859-863.

53. McMichael, A.J.; Wilkinson, P.; Kovats, R.S.; Pattenden, S.; Hajat, S.; Armstrong, B.; Vajanapoom, N.; Niciu, E.M.; Mahomed, H.; Kingkeow, C.; Kosnik, M.; O’Neill, M.S.; Romieu, I.; Ramirez-Aguilar, M.; Barreto, M.L.; Gouveia, N.; Nikiforov, B. International study of temperature, heat and urban mortality: The "ISOTHURM" project. Int. J. Epidemiol. 2008, 37, 1121-1131. doi:10.1093/ije/dyn086

54. Jendritzky, G., Staiger, H., Bucher, K., Graetz, A., Laschewski, G.: The Perceived Temperature: The Method of the Deutscher Wetterdienst for the Assessment of Cold Stress and Heat Load for the Human Body. Environ. Sci. 1-10 (2000). doi:10.1007/s00484-011-0409-6

55. Batista, R.; Camponogara, G.; Gonçalves, F. Caracterização da variabilidade anual de índices de conforto térmico humano e comparação entre estes, para o Estado de São Paulo. Congresso Brasileiro de Meteorologia (CBMET), Belém, Brazil, 2010.

56. Tseng, C.M.; Chen, Y.T.; Ou, S.M.; Hsiao, Y.H.; Li, S.Y.; Wang, S.J.; Yang, A.C.; Chen, T.J.; Perng, D.W. The Effect of Cold Temperature on Increased Exacerbation of Chronic Obstructive Pulmonary Disease: A Nationwide Study. PLoS One 2013, 8, 1-7. doi:10.1371/journal.pone.0057066

57. Brunekreef, B.; Forsberg, B. Epidemiological evidence of effects of coarse airborne particles on health. Eur. Respir. J. 2005, 26, 309-318. doi:10.1183/09031936.05.00001805

58. Schwartz, J.; Samet, J.M.; Patz, J.A. Hospital admissions for heart disease: The effects of temperature and humidity. Epidemiology 2004, 15, 755-761. doi:10.1097/01.ede.0000134875.15919.0f

59. Cheshire, W.P. Thermoregulatory disorders and illness related to heat and cold stress. Auton. Neurosci. Basic Clin. 2016, 196, 91-104. doi:10.1016/j.autneu.2016.01.001 